\title{
Editorial
}

Community Genetics

\section{Public Health Genetics - Experiences and Challenges}

\author{
Angela Brand $^{a}$ Peter Schröder ${ }^{b}$ \\ ${ }^{a}$ German Center for Public Health Genomics and ${ }^{b}$ Institute of Public Health, North Rhine-Westphalia, Bielefeld, \\ Germany
}

All contributions to this special issue of Community Genetics are based on presentations given at the First International Symposium on Public Health Genetics (PHG) at the Center for Interdisciplinary Research $(\mathrm{ZiF})$ in Bielefeld, Germany, in February 2004.

Each scientific discipline and each field of research perceive reality in a specific way. Not only for its description scientists develop their own language, but also their research subjects and methods are highly specialized. Nevertheless, the principle of specialization requires interdisciplinary research as a complement in order to exploit the scientific potentials of innovation to the highest possible extent. The $\mathrm{ZiF}$ is an internationally operating Institute for Advanced Studies, well known as a 'think tank' for interdisciplinary research projects from all scientific fields. In 2003-2004 it hosted the PHG Task Force and thus offered a unique institutional frame for implementing the emerging field of PHG in Germany (www. public-health-genetics.org). This Task Force consisted of three scientific organizers from various backgrounds, four resident fellows with different outstanding competencies as well as over 40 cooperating partners from research, politics and practice. It was supported by the North Rhine-Westphalian Ministry of Health, Social Affairs, Women and Family, by the Stifterverband für die Deutsche Wissenschaft (Endowment Association for German Research) and by the AOK Bundesverband (Federal Association of the AOK, a German health insur- ance). With co-sponsorship of the Friedrich Ebert Foundation, a policy paper had been published, which has been widely distributed to German policymakers. It identified specific areas in policies, practice and research where immediate action in the field of PHG is needed. For their work, the $\mathrm{ZiF}$ Task Force recently received the Johann Joachim Becher Award 2004.

By and large, the $\mathrm{ZiF}$ Task Force shared the view that the integration of genomics into public health represents progress in healthcare and an opportunity in rethinking the impact of human genetic variation on health and disease in every condition of public health interest such as effective prevention (e.g. there is the potential of stratified prevention strategies instead of individualized prevention or 'one strategy for all'). Opportunities for immediate action include strategic planning across health programs, developing genomic competencies among health professionals, enhancing surveillance and epidemiologic capacity to aid evidence-based policy-making, building partnerships and seeking input from stakeholders and incorporating information about genomics into health communication.

As initially mentioned, from February 19 to 21, 2004, this Task Force organized the First International Conference on PHG entitled 'Public Health Genetics - Experiences and Challenges' (http://www.public-health-genetics.org), thus establishing a national as well as an international interdisciplinary cooperation network for long-term

\section{KARGER \\ Fax +4161306 1234 \\ E-Mail karger@karger.ch}

www.karger.com
(C) 2006 S. Karger AG, Basel

$1422-2795 / 06 / 0091-0005 \$ 23.50 / 0$

Accessible online at:

www.karger.com/cmg
Prof. Dr. med. Angela Brand, MPH

Director, German Center for Public Health Genomics, University of Applied Sciences Kurt-Schumacher-Strasse 6

DE-33615 Bielefeld (Germany)

Tel. +49521 10678 64, E-Mail angela.brand@fh-bielefeld.de 
collaboration. The conference was supported by the Robert Bosch Foundation. This special issue of Community Genetics will reflect the discussion among geneticists, epidemiologists, social scientists, ethicists, public health experts and policy-makers. It will make an important contribution to the fields of public health and community genetics.

Pivotal presentations of the symposium are presented here. They give critical input regarding the question of integrating genomics into public health and report from public health activities in Europe, the US and Canada to accompany the advances in genomics and its implications for public health.

Public health practice has to date concerned itself with environmental determinants of health and disease and has paid scant attention to genetic variations within the population. The advances brought about by genomics are changing these perceptions. Many predict that this knowledge will enable health promotion messages and disease prevention programs to be specifically directed at susceptible individuals or at subgroups of a population, based on their genetic profile. Obviously, the integration of genomics into public health research, policy and practice will be one of the most important challenges in the future that our health care systems will face. But which consequences can be drawn from this knowledge and how can this knowledge be responsibly translated into policies and practice? The necessity of weighing benefits and risks of predictive genetic tests, the necessity of assessing the benefits of preventive strategies as well as the necessity of analyzing complex new problems (such as the availability and equal access to these services as well as potential discrimination) support the idea that public health should get involved and moreover take a leading role. This is the task of PHG. In some countries and scientific communities, the discussion of the current issues of PHG has up to now neither been established nor institutionalized. Thus public health in those countries runs the risk of ignoring pioneering developments which are presently taking place and shows that the discussion of these issues is in its infancy.

Likely benefits as well as potential risks of the integration of genomics into public health interventions (assessment) should be identified. The framework or corridors for effective, efficient and socially acceptable policies should be described (policy development), and steps and ways should be proposed to assure these policies in public health practice (assurance). At the same time, these three steps ('public health trias') describe the core functions of public health agencies at all levels of government. Thus, the public health trias had been used as an appropriate method to structure the presentations of the international symposium.

In a feature article, Neil A. Holtzman [1] - who gave the invited evening lecture of the symposium - is asking the question: 'What role for Public Health Genetics?' He concluded that the main task for public health lies in newborn screening and in the control of private genetic services rather than integrating further genetic services into public health.

Assessment: Marta Gwinn and Muin J. Khoury [2] present their view how genomic knowledge may be of benefit in public health. In their opinion, it is still a long way that can and should be pursued accompanied by public health organizations, e.g. their home institution, the Centers of Disease Control and Prevention in Atlanta, Ga., USA.

From a Canadian perspective, Ingeborg Blancquaert [3] introduces an example how public scientific advisory bodies may work in the context of PHG. The Quebec Agency for Health Services Research and Technology Assessment, AETMIS (l'Agence d'évaluation des technologies et des modes d'intervention en santé), is an agency conducting health technology assessments and counseling stakeholders of PHG at professional, institutional and policy level.

Policy Development: Peter Dabrock [4] discusses societal challenges of PHG from the standpoint of an ethicist. He sees justice at the fundamental norm for the issues concerned and presents his version of a capabilities approach as an adequate concept of justice that may help to resolve the fundamental conflict between respect for autonomy and common welfare arising from questions of PHG.

The sociologist Wolfgang van den Daele [5] pursues the matter if coercive preventive strategies - forcing people to undergo genetic testing - might be a consequence from integrating genomics into public health. However, he argues that given the current social values, professional orientations and legal and political cultures in Western Europe and the United States this is very unlikely to happen except maybe to protect third parties.

Assurance: Among controversially discussed technologies with relevance to $\mathrm{PHG}$ is pharmacogenomics. Regine Kollek et al. [6] conducted a systematic literature review and argued that due to the current state of pharmacogenomics, this technology can only be considered as an 'add-on' technology when trying to prevent adverse drug reactions. As PHG will largely deal with complex human 
diseases, regarding the impact of genetic factors, large study populations are needed.

PopGen is a large-scale, environmental, genetic, epidemiological project conducted in a northern part of Germany. Michael Krawczak et al. [7] describe the study design and provide early results and future plans of this paradigmatic PHG-relevant approach.

Erdmute Kunstmann and Jörg T. Epplen [8] are geneticists and genetic counselors experienced in monogenetic disease counseling in the currently employed human genetics paradigm. They state that the objectives of public health would indirectly be pursued with human genetic counseling. Counseling, however, has to focus on the individual's interest alone and may not have any primary public health motivation.

In a final paper on perspectives Angela Brand et al. [9] report on current projects and institutionalized European and global activities that integrate genomics into public health research, policy and practice.

$\mathrm{We}$, the guest editors, would especially like to thank Leo ten Kate, the Editor-in-Chief of Community Genetics and a pioneer in community genetics in Europe, for inviting us to publish the presentations of the First International Symposium on PHG in this special issue of the journal.

We also gratefully acknowledge the help of the excellent team of the $\mathrm{ZiF}$ as well as the scientific organizers, fellows and cooperating partners of the ZiF-PHG Task Force. In addition, we are very thankful for the support given to us by the Institute of Public Health, North RhineWestphalia, the Ministry of Health, Social Affairs, Women and Family of North Rhine-Westphalia, the Stifterverband für die Deutsche Wissenschaft, the AOK Bundesverband, the Friedrich Ebert Foundation and - last, but not least - the Robert Bosch Foundation. Constant and never-ending support came from Esther Lawrence (Editorial Office of the Karger Medical and Scientific Publishers in Basel, Switzerland). We had been very fortunate to work with her.

\section{References}

1 Holtzman NA: What role for public health in genetics and vice versa? Community Genet 2006;9:8-20.

2 Gwinn M, Khoury MJ: Genomics and public health in the United States: signposts on the translation highway. Community Genet 2006; 9:21-26.

3 Blancquaert I: Managing partnerships and impact on decision-making: the example of health technology assessment in genetics. Community Genet 2006:9:27-33.

4 Dabrock P: Public health genetics and social justice. Community Genet 2006;9:34-39.
5 van den Daele W: The spectre of coercion: is public health genetics the route to policies of enforced disease prevention? Community Genet 2006;9:40-49.

6 Kollek R, van Aken J, Feuerstein G, Schmedders M: Pharmacogenetics, adverse drug reactions and public health. Community Genet 2006;9:50-54.
7 Krawczak M, Nikolaus S, von Eberstein H, Croucher PJP, El Mokhtari NE, Schreiber S: PopGen: population-based recruitment of patients and controls for the analysis of complex genotype-phenotype relationships. Community Gene 2006;9:55-61.

8 Kunstmann E, Epplen JT: Genetic counseling for the public? Community Genet 2006;9:6266.

9 Brand A, Schröder P, Brand H, Zimmern R: Getting ready for the future: integration of genomics into public health research, policy and practise in Europe and globally. Community Genet 2006;9:67-71. 